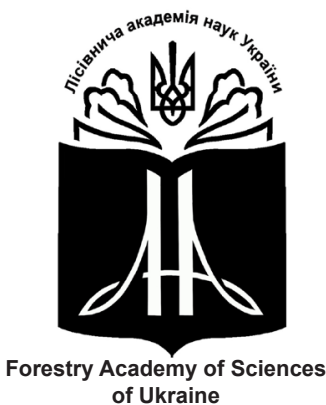

of Ukraine

Наукові праці Лісівничої академії наук України Proceedings of the Forestry Academy of Sciences of Ukraine

http://fasu.nltu.edu.ua https://doi.org/10.15421/411802

Article received 2018.02.23

Article accepted 2018.05.31
ISSN 1991-606X print

ISSN 2616-5015 online

(a) $\triangle$ Correspondence author

Vasyl Olijnyk

klz.pu.if.ua@ukr.net

Shevchenko st., 57, Ivano-Frankivsk, 76018, Ukraine

УДК 630.116(23)

\title{
Водорегулювальна роль лісистості водозборів Горган
}

\author{
В.С. Олійник' ${ }^{1}$ А.Ю. Рак²
}

Розглянуто вплив лісу на складники водного балансу і режим річкового стоку в умовах висотної поясності гірського району Горган в Украӥнських Карпатах. 3'ясовано, що із збільшенням висоти гірського рельєфу зростає сума річних опадів, схиловий і підземний види стоку води, зменшується сумарне випаровування вологи і транспірачія деревостанів, а також збільшується лісистість водозборів, змінюється співвідношення площ ялинових і букових лісів. Охарактеризовано величини сумарного випаровування вологи лісом і польовими угіддями, а також транспіраиії насаджень залежно від гіпсометричних рівнів гірських схилів. Отримано дані щодо збільшення лісом випаровування вологи порівняно з польовими угіддями впродовж року і вегетаційного сезону. Наведено кількісні показники лісистості водозборів, річних опадів, стоку води і випаровування вологи для висотних поясів - буково-ялищевих, буково-ялищево-ялинових і ялинових лісів.

Проаналізовано особливості формування і проходження паводкового стоку води залежно від специфіки гірських природних умов. Отримано емпіричні формули щодо залежнності основних характеристик паводків від лісистості і площі водозборів. Встановлено, що ліс, порівняно з польовими угіддями, здатний зменшувати максимальні піки паводків на 20\% і збільшувати їх тривалість у два рази.

Виявлено, що у гідрологічному відношенні найбільш значуща роль лісу на невеликих водозборах площею менше 100 км², у зв'язку з чим вони можуть слугувати об'єктами для оптимізаиії лісистості і екологічного удосконалення рубок головного користування. Рекомендовано також зменшувати лісоексплуатаційну діяльність по мірі збільшення висоти гірського рельєфу.

Ключові слова: опади; випаровування вологи; транспірація деревостанів; стік води; паводки; інтериепція; висота місцевості; польові угіддя; трунти.

Вступ. У комплексі поліфункціонального значення лісів Карпат чільне місце належить їх захисним, особливо - водорегулювальним властивостям, які визначають ступінь запобігання частих паводків, ерозійно-селевих і зсувних процесів. На цей час у науковій літературі відносно добре висвітлена стокорегулювальна роль лісу, зокрема ії висотнопоясні зміни (Chubatyi, 1984, Olijnyk et al., 2015). Проте для окремих орографічних частин регіону ці питання залишаються слабко висвітленими. В особливій мірі це стосується гірського ландшафту
Горган, найбільш складного для Карпат у геоморфологічному, гідрокліматичному і лісорослинному відношеннях. У його геологічній основі залягають стійкі до вивітрювання пісковики, які зумовлюють поширення кам'янистих розсипів і малопотужних грунтів. Абсолютні висоти тут сягають 1800 м, а вертикальне розчленування рельєфу - 800-950 м (Herenchuk et al., 1964). Горгани - одна з найбільш зволожених частин Карпат із кількістю опадів 10001500 мм і значною водністю річок, що місцями сягає 1000 мм і більше на рік (Kiriljuk, 1985). Не-

Олійник Василь Степанович - дійсний член Лісівничої академії наук України, доктор сільськогосподарських наук, професор, завідувач кафедри лісознавства. Прикарпатський національний університет імені Василя Стефаника, вул. Шевченка, 57, м. Івано-Франківськ, 76018, Україна. Тел.: +38-067-456-75-94. E- mail: klz. pu. if. ua@ukr.net

2 Рак Андрій Юрійович - аспірант кафедри лісознавства. Прикарпатський національний університет імені Василя Стефаника, вул. Шевченка, 57, м. Івано-Франківськ, 76018, Україна. Тел.: +38-097-745-82-42. E- mail: krab5454545@gmail.com 
зважаючи на високу лісистість ( $\approx 80 \%)$, рельєфнометерологічні чинники зумовлюють тут найбільш інтенсивні для Карпат шкідливі стихійні процеси паводки, селі і осипні явища. Актуальність проблеми полягає у посиленні захисних функцій лісу цієї частини Карпат.

Об'єкти і методика дослідження. Об ' $\epsilon$ 'm досліджень - ліси гірських водозборів Горган. Предмет досліджень - водорегулювальна роль лісів.

Мета роботи - кількісна оцінка впливу лісистості водозборів Горган на сумарне випаровування вологи й максимальний паводковий стік річок з урахуванням природної специфіки гірського регіону.

Вплив лісу на водний режим вивчали на 10 горганських водозборах, на яких у другій половині ХХ ст. найбільш повно проводилися спостереження за стоком води (Gorobtcevich N.P., \& Egorova E. M., 1976, Sakun, L. V, 1984). Їх площі коливаються від

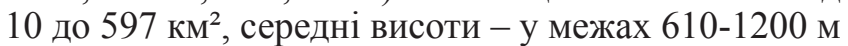
н.р.м. і лісистість - від 56 до $87 \%$. Загалом водозбори охоплюють весь природний спектр висотного діапазону Горган - від підніжжя гір (500 м) до найвищих гіпсометричних рівнів (>1800 м) і репрезентативно відображають лісорослинне різноманіття досліджуваного регіону.

За допомогою загальноприйнятих у гідрології формул для водозборів розраховувалися річні показники сумарного, схилового і підземного стоку води, максимальних рівнів паводків та їх тривалості. Величину кількості опадів запозичували із публікацій (Halushchenko, 1977, Kiriljuk, 1985), а для невисвітлених у них випадків визначали на основі кліматологічних довідників. Річне сумарне випаровування вологи встановлювали воднобалансовим методом. Показники лісистості й породного складу лісів розраховували за матеріалами лісовпорядкування. До статистичного аналізу залучали також опубліковані у накових працях (Holubets, 2003, Kisilevskyi-Babinin, 1965, Shpak, 1968, Diakov, 1976, Chubatyi, 1972, Uvarov, 1973, Olijnyk, 2013) показники випаровування вологи у лісі й на польових угіддях за вегетаційні періоду року, що включають 46 ділянок, розміщених у висотному діапазоні гірської системи в межах 500-1500 м н.р.м.

Результати та обговорення. Наведені у табл. 1 характеристики лісового покриву та багаторічні показники водного балансу й режиму стоку річок водозборів Горган свідчать, що збільшення гіпсометричних рівнів зумовлює зміну природних чинників формування водного режиму та їх складників. Зокрема, із зростанням висоти басейнів (h, м н. р. м.) чітко зростає кількість річних опадів (Р, мм) :

$$
\mathrm{P}=0,71 \cdot \mathrm{h}+556 \text { при } \mathrm{r}=0,87 \pm 0,08 \text {. }
$$

Від підніжжя гірського масиву (500 м) до верхньої межі лісу (1500 м) кількість опадів пересічно зростає із 910 до 1610 мм. Градієнт їх збільшення становить 71 мм на 100 м підняття висоти.

Із збільшенням висоти водозборів зростає площа лісових угідь та частка у них ялинових насаджень $(\mathrm{r}=0,72)$. Водночас у цьому напрямку зменшуються площі букових лісостанів $(\mathrm{r}=-0,65)$. Залежність основного лісогідрологічного чинника - частки лісистості водозборів (f,$\%$ ) від їх висотного розміщення (h, м н. p. м.) є наступною:

$$
\mathrm{f}_{\text {л }}=0,053 \cdot \mathrm{h}+25 \text { при } \mathrm{r}=0,91 \pm 0,05 \text {. }
$$

Отже, у висотному діапазоні Горган в межах 500-1500 м лісистість водозборів зростає пересічно з 52 до $100 \%$.

Збільшення кількості опадів із підняттям висоти місцевості сприяє зростанню водності річок та iї складників - схилового і підземного видів живлення. У статистичному відношенні ця залежність оцінюється досить високими коефіцієнтами кореляції $(0,83 \ldots 0,87)$. У той же час зменшення ресурсів тепла із збільшенням висоти гірських схилів зумовлює зворотній ефект у формуванні сумарного випаровування вологи, а саме - iі зменшення за збільшення гіпсометричних рівнів річкових басейнів $(\mathrm{r}=-0,71)$. Загалом досить чітко виражена висотно-поясна зміна гідрокліматичних і лісорослинних умов. Єдина гідрологічна ланка, яка майже не залежить від чинника висоти водозборів - паводковий стік $(\mathrm{r}=-0,13 \ldots-0,15)$. Його формування пов'язане з інтегральним впливом зливових опадів, лісистістю і площею водозборів. У цьому відношенні залежність висоти водозборів від цих чинників оцінюються коефіцієнтами кореляції від 0,55 до 0,92-0,98.

У комплексі гідрологічних властивостей лісу найкраще вивчений його вплив на генезис річкового стоку та його режим (Olijnyk, 2013, Chubatyi, 1984). У той же час не визначена кількісна оцінка впливу лісу на випаровування вологи, яке сприяє підсушуванню грунтового блоку, що своєю чергою уповільнює процеси формування паводків i пов’ язаних із ними ерозійно-селеві і зсувні явища.

Сумарне випаровування вологи лісу складають транспірація деревостанів, затримання опадів лісовим наметом (інтерцепція) та фізичне випаровування 3 поверхні грунту. У центральній частині Карпат на них, відповідно, припадає 46, 42 і 12\% цієї статті водного балансу (Shpak, 1968). На відкритих ділянках сумарне випаровування формують фізичне випаровування 3 поверхні грунту та випаровування вегетативними органами надгрунтового вкриття. І3 збільшенням висоти гірських схилів усі показники випаровування вологи зменшуються. Найкраще цей аспект виражений впродовж вегетаційного періоду, коли відбувається значне біологічне споживання вологи лісовою рослинністю. Здійснений кореляційний аналіз показників випаровування вологи у діапазоні гіпсометричних рівнів 500-1500 м н.р.м. (Holubets, 2003, Kisilevskyi-Babinin, 1965, Olijnyk, 2013, Uvarov, 1973, Shpak, 1968) показав, що сумарне випаровування 3 поля і лісу та транспірація деревостанів найбільше залежать від висоти місцевості $(\mathrm{r}=-0,79 \ldots-0,86)$. Значно меншою мірою цей аспект властивий для інтерцепції $(\mathrm{r}=-0,61)$. Фізичне випаровування вологи з поверхні грунту в лісах не пов' язане із висотою рельєфу $(\mathrm{r}=-0,10)$.

Впродовж вегетаційного періоду сумарне випаровування лісу на 150 мм більше, ніж польових ді- 
лянок (табл. 2). В обох випадках від підніжжя гір до верхньої межі лісу випаровування зменшується. При цьому найбільш різко зменшується транспірація деревостанів - у два рази. Біля підніжжя гір вона формує $63 \%$ від сумарного випаровування, а на висоті 1500 м - лише $43 \%$. Таке зменшення, ймовірно, пов'язане з вертикальним падінням температури повітря і скороченням періоду активної вегетації.

Характеристики лісового покриву і показники водного режиму водозборів Горган

\begin{tabular}{|c|c|c|c|c|c|c|c|c|c|c|}
\hline \multirow[b]{2}{*}{$\begin{array}{l}\text { Характеристики водозборів } \\
\text { і показники водного режиму }\end{array}$} & \multicolumn{10}{|c|}{ Водозбори (річка - пункт) } \\
\hline & 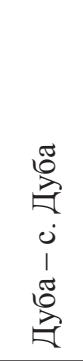 & 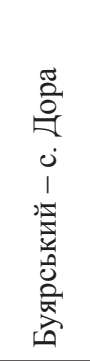 & 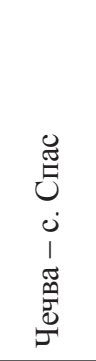 & 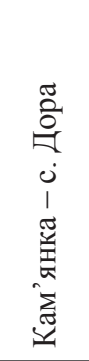 & 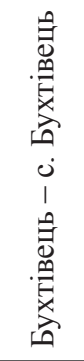 & 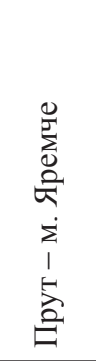 & 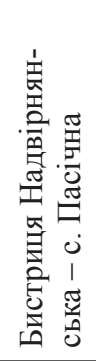 & 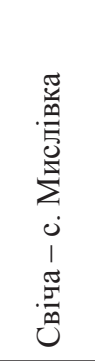 & 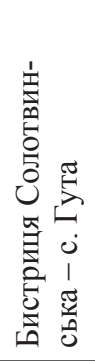 & 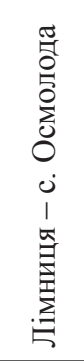 \\
\hline & \multicolumn{10}{|c|}{ Загальні характеристики водозборів } \\
\hline Середня висота, м н. р. м. & 610 & 720 & 820 & 870 & 880 & 990 & 1000 & 1000 & 1100 & 1200 \\
\hline Площа, км² & 35,1 & 10,0 & 269 & 18,1 & 33,8 & 597 & 482 & 201 & 112 & 203 \\
\hline Лісова площа, \% & 57 & 66 & 79 & 88 & 76 & 81 & 88 & 93 & 86 & 90 \\
\hline Лісистість, \% & 56 & 60 & 72 & 76 & 68 & 79 & 79 & 87 & 80 & 85 \\
\hline Частка букових лісів, \% & 44 & 84 & 27 & 66 & 69 & 9 & 9 & 3 & 4 & 3 \\
\hline \multirow[t]{2}{*}{ Частка ялинових лісів, \% } & 47 & 5 & 54 & 15 & 28 & 83 & 84 & 96 & 83 & 87 \\
\hline & \multicolumn{10}{|c|}{ Показники водного режиму водозборів } \\
\hline Річні опади, мм & 1009 & 1072 & 1106 & 1165 & 1174 & 1168 & 1202 & 1397 & 1261 & 1475 \\
\hline Сумарний стік, мм & 457 & 518 & 568 & 615 & 623 & 620 & 641 & 861 & 776 & 1012 \\
\hline Коефіцієнт стоку & 0,45 & 0,48 & 0,51 & 0,53 & 0,53 & 0,53 & 0,53 & 0,62 & 0,62 & 0,69 \\
\hline Схиловий стік, мм & 409 & 459 & 489 & 532 & 545 & 511 & 533 & 715 & 650 & 814 \\
\hline Підземний стік, мм & 48 & 59 & 79 & 83 & 78 & 109 & 108 & 146 & 126 & 198 \\
\hline Сумарне випаровування, мм & 552 & 554 & 539 & 550 & 551 & 548 & 561 & 536 & 485 & 463 \\
\hline Найбільший стік паводків, л · $\mathrm{c}^{-1} 3$ км² & 613 & 678 & 602 & 624 & 848 & 447 & 434 & 585 & 826 & 381 \\
\hline Середня тривалість паводків, доби & 7,0 & 5,4 & 7,8 & 7,8 & - & 8,5 & 10,5 & 10,1 & 9,3 & 8,5 \\
\hline
\end{tabular}

Кількісні показники випаровування вологи полем, лісом і транспірації деревостанів

Таблиия 2 залежно від висоти схилів

\begin{tabular}{|c|c|c|c|c|}
\hline \multirow{2}{*}{$\begin{array}{c}\text { Види } \\
\text { випаровування }\end{array}$} & \multirow{2}{*}{$\begin{array}{c}\text { Коефіцієнти кореляції } \\
\text { випаровування } \\
\text { з висотою }\end{array}$} & \multirow{2}{*}{$\begin{array}{c}\text { Рівняння регресії } \\
\text { випаровування (мм) } \\
\text { з висотою, (h, м н. p. м.) }\end{array}$} & \multicolumn{2}{|c|}{ Показники випаровування, мм } \\
\hline & & & $\begin{array}{c}\text { біля підніжжя } \\
\text { гір }(500 \mathrm{M}) \\
\end{array}$ & $\begin{array}{c}\text { на верхній межі } \\
\text { лісу }(1500 \text { м) }\end{array}$ \\
\hline Сумарне поля $\left(\mathrm{E}_{\text {п }}\right)$ & $-0,79 \pm 0,13$ & $\mathrm{E}_{\Pi}=482-0,155 \cdot \mathrm{h}$ & 404 & 249 \\
\hline Сумарне лісу (E $)$ & $-0,86 \pm 0,09$ & $\mathrm{E}_{\mathrm{л}}=625-0,146 \cdot \mathrm{h}$ & 552 & 406 \\
\hline $\begin{array}{l}\text { Транспірація } \\
\text { деревостанів }\left(\mathrm{E}_{\mathrm{T}}\right)\end{array}$ & $-0,84 \pm 0,10$ & $\mathrm{E}_{\mathrm{T}}=436-0,174 \cdot \mathrm{h}$ & 349 & 175 \\
\hline
\end{tabular}

Процеси зменшення випаровування вологи під впливом лісу і висоти схилів спостерігається не лише у період вегетації, але й впродовж року. Це наочно проявляється на території річкових басейнів, на яких залежність сумарного випаровування (Е, мм) від висоти (h, м) і лісистості (f, \%) в інтегральному вигляді характеризується наступною емпіричною формулою:

$$
\mathrm{E}=2,78 \cdot \mathrm{f}_{\text {л }}-0,28 \cdot \mathrm{h}+586 \text { при } \mathrm{R}=0,80 \pm 0,12 \text {. }
$$

Отже, на кожні 100 м підняття висоти випаровування зменшується на 28 мм, а збільшення лісистості на $1 \%$ призводить до збільшення випаровуваності на 2,8 мм. Загалом ліс у Горганах сприяє збільшенню випаровування вологи на 280 мм порівняно із польовими угіддями. У річному атмос- 
ферному зволоженні, яке тут становить $\approx 1200$ мм, ця позитивна роль лісу потенційно сягає $23 \%$.

На основі формул (1)-(3) для лісорослинних поясів Горган розраховані середні показники лісистості і водного балансу (табл. 3). Найменшими величинами кількості опадів і стоку води та найбільшим випаровуванням вологи характеризуються низькогірні буково-ялицеві ліси. У смузі буковоялицево-ялинових лісів кількість опадів і величина стоку зростають, а випаровування - зменшується. Найкраще ці процеси виражені у середньогірних ялинових лісах. Отримані дані підтверджують доцільність зменшення лісокористування із збільшенням висоти схилів, оскільки під його впливом зменшується випаровування, зростає інтенсивність стоку води й на тривалий час затягується відновлення водного режиму при наступному формуванні нового покоління лісу.

Лісистість і багаторічні складники водного балансу різних лісорослинних поясів Горган

Табличя 3

\begin{tabular}{lccccc}
\hline \multicolumn{1}{c}{ Лісорослиний пояс } & $\begin{array}{c}\text { Лісистість, } \\
\text { \% }\end{array}$ & $\begin{array}{c}\text { Опади, } \\
\text { мм С }\end{array}$ & $\begin{array}{c}\text { Сік води, } \\
\text { мм }\end{array}$ & $\begin{array}{c}\text { Коефіцієнт } \\
\text { стоку }\end{array}$ & $\begin{array}{c}\text { Випаровування } \\
\text { вологи, мм }\end{array}$ \\
\hline 500-800 м н.р.м. (буково-ялицеві ліси) & 70 & 1015 & 415 & 0,41 & 600 \\
800-1200 м н.р.м. (буково-ялицево-ялинові ліси) & 78 & 1261 & 741 & 0,59 & 520 \\
1200-1500 м н.р.м. (ялинові ліси) & 98 & 1508 & 1028 & 0,68 & 480 \\
\hline
\end{tabular}

Підвищена випаровувальна здатність лісу порівняно з безлісими ділянками впливає на інтенсивність формування паводків. Зокрема, на польових угіддях із слабким випаровуванням і вологими грунтами паводковий стік виникає вже при опадах величиною в 10 мм, а в лісових умовах, де грунти підсушуються інтенсивним випаровуванням, він починає формуватися опадами понад 25 мм у буковому поясі і більшими ніж 15-20 мм - в ялинових лісах (Olijnyk, 2013).

Особливої уваги заслуговує питання впливу лісу на максимальний («піковий») стік паводків, що є найнебезпечнішим у господарському і екологічному відношеннях. Ця характеристика стоку, на відміну від інших показників водного режиму, не пов'язана із висотним розташуванням водозборів i значною мірою залежить від розміру їхньої площі. Iз ii збільшенням зменшується охоплення теритоpiï зливовими опадами, що сприяє редукції (падінню) показника максимального стоку (Mihajlov \& Dobrovol'skij, 1991). Певною мірою цей процес підсилюється позитивним паводкорегулювальним впливом лісу. Інтегральний вплив площі водозборів $\left(\mathrm{F}, \mathrm{kM}^{2}\right)$ та їхньої лісистості (fл, \%) на максимальні модулі паводків $\left(\mathrm{M}_{\text {мах }}, \pi^{-1} 3 \mathrm{KM}^{2}\right)$ у Горганах характеризується такою емпіричною формулою:

$\mathrm{M}_{\text {мах }}=801-1,41 \cdot \mathrm{f}_{\text {л }}-0,48 \cdot \mathrm{F}$ при $\mathrm{R}=0,67 \pm 0,17$. (4)

Отже, у регіоні досліджень ліс, порівняно 3 полем, потенційно здатний зменшувати інтенсивність паводків на 141 л·с ${ }^{-1} 3$ км² (пересічно на 20\%). Оскільки в регіоні досліджень мінімальна лісистість становить 52\%, а максимальна - сягає 100\%, то у цьому діапазоні вона може зменшувати піки шкідливого стоку із 630 до 565 л $\cdot \mathrm{c}^{-1} 3$ км² (приблизно на $11 \%$ ). Ці показники майже у два рази менші, ніж на водозборах інших орографічних утворень Карпат - Бескид, Чорногори, ВододільноВерховинської області (Olijnyk et al., 2015). Слабший вплив лісу на піки паводків у Горганах очевидно пов'язаний із значною складністю рельєфу, неглибоким заляганням геологічного фундаменту, що $є$ причиною інтенсивної водовіддачі під час паводкових періодів. У цих умовах необхідне обережне застосування лісоексплуатаційної діяльності, оскільки вона може сприяти інтенсифікації шкідливого стоку води.

Поряд 3 кількісною оцінкою впливу лісу на максимальний стік води, значний інтерес представляє інше не з'ясоване для Карпат лісогідрологічне питання - збільшення лісовим покривом тривалості проходження паводків. Цей аспект пов'язаний із тим, що чим тривалість паводків довша, тим менші їхні руйнівні наслідки. Статистичний аналіз показників цього виду стоку для умов Горган показав, що його тривалість (L, доби) значно залежить від площі й лісистості водозборів і характеризується таким рівнянням:

$\mathrm{L}=0,104 \cdot \mathrm{f}_{\text {л }}+0,002 \cdot \mathrm{F}-0,1$ при $\mathrm{R}=0,83 \pm 0,10$. (5)

Отже, збільшення площ водозборів річок із мінімальної величини (10 км²) до максимальних розмі-

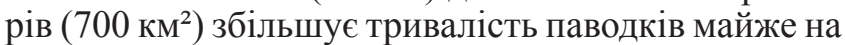
півтори доби. Ще суттєвіше впливає на цей процес лісистість водозборів. Її збільшення у Горганах від 50 до 100\% сприяє зростанню тривалості паводків на малих водозборах в 2,1, а на найбільших - в 1,8 рази. Загалом формули (4) i (5) підтверджують найвищу значущість паводкорегулювальної ролі лісу на малих водозборах площею до 100 км², у зв'язку 3 чим вони можуть слугувати основними об' єктами підвищення лісистості й застосування екологічно виваженої лісогосподарської діяльності.

Що ж стосується процесів впливу лісу на річні водні ресурси та їх складники, то підвищена випаровувальна здатність лісу теоретично мала б дещо зменшувати об'єми сумарного і схилового видів стоку, а приріст лісистості сприяти збільшенню підземного живлення рік. Проте в умовах складного рельєфу Горган, високої лісистості і надмірного атмосферного зволоження ця закономірність майже не виражена. Зв'язки лісистості із цими показниками стоку є високими ( $\mathrm{r}=0,81-0,87)$, але меншими, ніж зв'язки з опадами й висотою водо- 
зборів $(r=0,86-0,92)$. Ймовірно, вплив провідних абіотичних чинників - висоти місцевості, рельєфу i опадів значно елімінують позитивну стокоформувальну роль біотичного фактора - лісового покриву. Враховуючи таку гідролого-лісівничу ситуацію, для Горган можна рекомендувати для використання кількісні показники впливу лісистості водозборів на величину річкового стоку, раніше отримані для північно-східного мегасхилу Карпат (Olijnyk, 2013).

Висновки. Гідрологічна роль лісів Горган формується під складним впливом низки абіотичних i біотичних чинників висотної поясності. Із збільшенням висоти водозборів зростають кількість атмосферних опадів і лісистість, змінюються співвідношення ялинових та букових деревостанів, зменшується сумарне випаровування вологи і зростають схиловий і підземні види живлення рік.

На тлі впливів таких чинників в Горганах добре виражений вплив лісу на сумарне випаровування вологи. Він, порівняно із польовими угіддями, здатний потенційно збільшувати цю ланку вологообігу на 280 мм (23\% від річних опадів), сприяючи тим самим підсушуванню грунтового блоку. Внаслідок такого впливу уповільнюються процеси формування паводків, зокрема на $20 \%$ зменшуються їх максимальні рівні і в два рази розтягується тривалість їхнього проходження.

У зв'язку 3 інтенсифікацією схилового стоку води у міру збільшення висоти місцевості необхідно інтенсивно впроваджувати екологічні засади лісокористування. Це стосується й невеликих водозборів площею до $100 \mathrm{kм}^{2}$ із розвинутим паводковим стоком.

\section{Бібліографічні посилання}

Chubatyi, O. V. (1984). Mountain forests - regulation of water regime. Uzhhorod: Karpaty (in Ukrainian).

Diakov, V.N. (1976). Influence of plant composition on the water regime of mountain soils in the Carpathians. Forestry, 1, 11-17 (in Russian).

Gorobtcevich N.P. \& Egorova E. M. (1976). Resources of surface waters of the USSR. Basic hydrological characteristics, 1, V. 6. Leningrad (in Russian).

Halushchenko, N. H. (1977). Water balance of the Dniester rivers. Works of UkrNYYHMY, 153, 125139 (in Russian).

Herenchuk, K. I., Koinov, M. M., \& Tsys, P. M., (1964). Natural-geographical division of the - Lviv and Podolsky economic districts. Lviv: Lviv University (in Ukrainian).

Holubets, M. A., Maryskevych, O. H., Krok, B. O. et al. (2003). Ecological potential of terrestrial ecosystems. Lviv: Polli (in Ukrainian).

Kiriljuk, M. I. (1985). Water balance. In Heat and water regime in the Ukrainian Carpathians, Leningrad: Gidrometeoizdat, 202-218 (in Russian).

Kisilevskyi-Babinin, R. H. (1965). Hydrological features of brown forest soils under plantations of different ages in the zone of oak and beech forests of the Carpathians. Forestry and agromelioration, 3, 151-160 (in Ukrainian).

Mihajlov, V. N., \& Dobrovol'skij, A. D. (1991). General hydrology. Moscow: Vysshaia Shkola (in Russian).

Olijnyk, V. S. (2013). Hydrological role of forests of the Ukrainian Carpathians. Ivano-Frankivsk: NAIR (in Ukrainian).

Olijnyk, V. S., Pankiv, N. I., Tkachuk, O. M., \& Blystiv, V. I. (2015). High-belt patterns of the control-role of the Carpathian Forests, Hydrology, hydrochemistry and hydroecology, 1 (36), 39-46 (in Ukrainian).

Sakun, L. V. (ed.) (1984). Materials of the Carpathian Station observations of mud flows control, 3, Kyiv (in Russian).

Shpak, I. S. (1968). Forest Impact on the Water Balance of Reservoirs. Kyiv: Scientific thought (in Russian).

Uvarov, L. A. (1973). Quantitative characteristics of the water regime of beech - fir - spruce forests of Gorgany. In Ye. F. Cherniak (ed.) Science to the forestry production of the Carpathians (pp. 74-82) Uzhorod: Karpaty (In Ukrainian).

\section{Водорегулирующая роль лесистости водосборов Горган}

\author{
В.С. Олийнык ${ }^{1}$, А.Ю. Рак ${ }^{2}$
}

В комплексе многофункционального значения лесов Карпат важное место принадлежит их водорегулирующим свойствам. В научной литературе относительно достаточно освещена стокорегулирующая роль горных лесов, в частности ее высотно-поясные изменения. Однако для отдельных орографических частей региона эти вопросы остаются малоисследоваными. В особой степени это относится к горному ландшафту Горган - наиболее сложному в Карпатах в природном отношении с интенсивными опасными стихийными явлениями. Для Горган очень актуальна количественная оценка влияния лесистости водосборов на основные показатели водного режима, особенно суммарное испарение влаги и максимальный паводковый сток рек.

В качестве объектов исследований выбраны все 10 горганских водосборов, на которых во второй половине XX века наиболее полно проводились

Олийнык Василий Степанович - действительный член Лесной академии наук Украины, доктор сельскохозяйственных наук, профессор, заведующий кафедры лесоведения, Прикарпатский национальный университет им. В. Стефаныка, ул. Шевченка, 57, г. Ивано-Франковск, 76018, Украина. Тел.: +38-067456-75-94. E-mail: klz.pu.if.ua@ukr.net

Рак Андрей Юрьевич - аспирант кафедры лесоведения, Прикарпатский национальный университет им. В. Стефаныка, ул. Шевченка, 57, г. Ивано-Франковск, 76018, Украина. Тел. +38-097-745-82-42. E- mail: krab5454545@gmail.com 
гидрологические наблюдения. Они охватывают высотный диапазон Горган от подножья гор (500 м) до наивысших гипсометрических уровней (> 1800 м) и репрезентативно отображают лесорастительное разнообразие исследуемого региона. Их площади колеблются от 10 до 597 км², средние высоты - в пределах 510-1200 метров над уровнем моря и лесистость - от 56 до $87 \%$. К анализу привлекались также литературные данные по показателям испарения влаги в лесу и на полевых угодьях за вегетационные периоды на разных высотных уровнях горной системы.

Исследования показали, что увеличение высотного размещения водосборов способствует изменению природных факторов формирования водного режима и его составляющих. От подножья горного массива до верхней границы леса (1500 м) осадки в среднем увеличиваются от 910 до 1610 мм, а лесистость водосборов расширяется с 52 до 100\%. Возрастание атмосферного увлажнения с подъемом высоты местности способствует возрастанию водности рек и ее составляющих - склонового и подземного видов питания. В это же время падения ресурсов тепла вместе с увеличением высоты горных склонов вызывает уменьшение суммарного испарения влаги.

В течение года лес, по сравнению с полевыми угодьями, увеличивает испарение влаги на 280 мм, а на протяжении вегетационного периода - на 150 мм. Наименьшим количеством осадков и стоком воды, а также наибольшим испарением влаги характеризуются низкогорные буково-пихтовые леса. В поясе буково-пихтово-елевых лесов осадки и сток воды возрастают, а испарение - уменьшается. Наиболее сильно эти процессы выражены в среднегорных елевых лесах, что подтверждает целесообразность уменьшения лесопользования с увеличением высоты склонов.

Лес ощутимо регулирует опасный в хозяйственном и экологическом отношениях сток паводков. По сравнению с полем, он потенциально способный уменьшить максимальные уровни павод-


личить продолжительность этого вида стока воды в 1,8-2,1 раза. Наиболее ощутимо паводкорегулирующая роль леса выражена на малых водос-

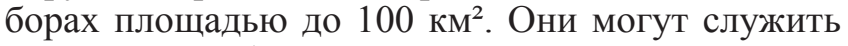
основными объектами для оптимизации лесистости и применения экологически взвешенной лесохозяйственной деятельности. В связи с интенсификацией склонового стока воды по мере увеличения высоты местности, в этом направлении необходимо также усиление экологизации лесопользования.

Ключевые слова: осадки; испарение влаги; транспирация древостоев; сток воды; паводки; интерцепция; высота местности; полевые угодья; почвы.

\section{Water regulating role of the forest cover of the Gorgany watersheds}

\author{
V. Olijnyk ${ }^{1}$, A. Rak ${ }^{2}$
}

In the complex of the multifunctional value of the Carpathian forests the prominent place belongs to their waternregulating properties. The drainage controlling role of the forest, in particular its high-altitude changes, is relatively well studied in the scientific literature. However, for some orographic parts of the region, these issues remain less investigated. In particular, this concerns the mountain landscape of Gorgany, which is the most complex in the Carpathians in the natural sense with intense harmful spontaneous phenomena. The quantitative assessment of the catchment areas forest cover influence on the main indicators of the water regime, especially the total evaporation of moisture and maximum flood drain of the rivers are rather topical issue.

The research objects were provided by all the 10 Gorgany watersheds, in which in the second half of the 20th century the hydrological observations were comprehensively conducted. They cover the highland range of the Gorgany from the foot of the mountains $(500 \mathrm{~m})$ to the highest hypsometric levels $(>1800 \mathrm{~m})$ and represent the variety of the forest vegetation of the studied region. Their area ranges from 10 to 597 $\mathrm{km}^{2}$, the average height - within 510-1200 mask and forest cover from 56 to $87 \%$. Literature data on the parameters of moisture evaporation in the forest and on the field during vegetation periods at different altitudinal levels of the mountain system were also included in the analysis.

The studies have shown that increasing the high-rise location of the watersheds contributes to the change in the natural factors of water regime formation and their components. From the foot of the mountain range to the upper limit of the forest $(1500 \mathrm{~m})$, precipitation rises from 910 to $1610 \mathrm{~mm}$, and the forest increases from 52 to $100 \%$. The increase of atmospheric humidification with elevation of the terrain contributes to the growth of wateriness of the rivers and their components - the sloping and underground kinds of their nutrition. At the same time, the fall of heat resources with an increase in the height of the mountain slopes causes a decrease in the total evaporation of moisture.

During the year forest, in comparison with field lands, increases the evaporation of moisture by

Vasyl Olijnyk - full Member of the Forestry Academy of Sciences of Ukraine, Doctor of Agricultural Sciences, Professor, Head of the Department of Forestry. Vasyl Stefanyk Precarpathian National University, Shevchenko str., 57, Ivano-Frankivsk, 76018, Ukraine. Tel.: +38-067- 456-75-94. E-mail: klz.pu.if.ua@ukr.net

Andrii Rak - Postgraduate student of the Department of Forestry. Vasyl Stefanyk Precarpathian National University, Shevchenko str., 57, Ivano-Frankivsk, 76018, Ukraine. Tel. +38-097-74582-42. E- mail: krab5454545@gmail.com 
$280 \mathrm{~mm}$, and during vegetation periods by $150 \mathrm{~mm}$. Low-altitude beech and fir forests are characterized by the lowest precipitation and drainage of water and the greatest evaporation of moisture. In the stripe of beech-fir-spruce precipitation and runoff increase and evaporation decreases. These processes are most evident in the mid-range mountain spruce forests. Such reaserch results indicate the expediency of reducing forest use with increasing slopes elevation.

Forest tangibly regulates the harmful floods in the economic and ecological aspects. It is potentially able to reduce the maximum flood levels by 141 liters from$\mathrm{km}^{2}$ (by roughly $20 \%$ ) compared to the field and increase the duration of this type of water drainage in 1.8-2.1 times. The highest significance of the flood control role of the forest is expressed in small watersheds of up to $100 \mathrm{~km}^{2}$. They can serve as the main objects of forestry optimization and the use of environmentally sound forest management. In connection with the intensification of the sloping drainage of water as the elevation of the area increases, in this direction implementation of environmental restrictions of forest use should also be intensified.

Key words: moisture evaporation; tree transpiration; water drainage; flooding; interception; elevation of terrain; field lands; soils. 